\title{
Intra-abdominal Abscess
}

National Cancer Institute

\section{Source}

National Cancer Institute. Intra-abdominal Abscess. NCI Thesaurus. Code C128326.

An abscess within the abdomen. 